\title{
LIGAND BASED PHARMACOPHORE MODELING, VIRTUAL SCREENING AND MOLECULAR DOCKING STUDIES TO DESIGN NOVEL PANCREATIC LIPASE INHIBITORS
}

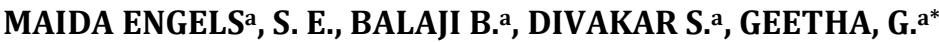 \\ aPSG College of Pharmacy, Tamilnadu, India 641004 \\ Email: ggeetha97@gmail.com
}

Received: 29 Nov 2016 Revised and Accepted: 14 Feb 2017

\begin{abstract}
Objective: To understand the essential structural features required for pancreatic lipase (PL) inhibitory activity and to design novel chemical entities, ligand-based pharmacophore modeling, virtual screening and docking studies were carried out.

Methods: The pharmacophore model was generated based on 133 compounds with PL inhibitory activity using PHASE. An external test set and decoy dataset methods were applied to validate the hypothesis and to retrieve potential PL inhibitors. The generated hypothesis model was further subjected to virtual screening and molecular docking studies.

Results: A five point pharmacophoric hypothesis model which consists of three hydrogen bond acceptor sites and two hydrophobic sites was developed. The generated pharmacophore gave significant 3D QSAR (three-dimensional Quantitative Structural Activity Relationship) model with ${ }^{2}$ of 0.9389 and $Q^{2}$ value of 0.4016 . After database screening, five molecules were found to have better glide scores and binding interactions with the active site amino acid residues.
\end{abstract}

Conclusion: As an outcome of this study, five hit molecules were suggested as potent PL inhibitors as they showed good glide scores as well as binding interactions with required active site amino acids. The five molecules obtained from this study may serve as potential leads for the development of promising anti-obesity agents.

Keywords: Pancreatic lipase, Atom based 3D-QSAR, Pharmacophore modeling, Virtual screening, Molecular docking

(C) 2017 The Authors. Published by Innovare Academic Sciences Pvt Ltd. This is an open access article under the CC BY license (http://creativecommons.org/licenses/by/4. 0/) DOI: http://dx.doi.org/10.22159/ijpps.2017v9i4.16392

\section{INTRODUCTION}

Obesity and excess weight are rapidly growing health hazards in the world. The 2014 WHO report indicates that on the whole, about $13 \%$ of the world's adult population (11\% of men and $15 \%$ of women) are obese. Obesity is complicated by its associated comorbidities which include cancer, diabetes, heart disease, and obstructive sleep apnea. The fundamental cause of obesity and overweight is an energy imbalance between calories consumed and calories expended. There are very few options for the treatment of obesity. They are as follows: Cannabinoid receptor type 1 (CB1R) antagonist (rimonabant ${ }^{\circledR}$ ), Anorectic agent (sibutramine, phentermine), and pancreatic lipase (PL) inhibitor orlistat. However, rimonabant has been withdrawn from the market due to concerns about increased risk of suicidal tendencies $[1,2]$. Anorectic agent sibutramine and phentermine were withdrawn due to cardiovascular issues and the potential for addiction respectively [3-5]. Orlistat, a pancreatic lipase inhibitor is the only peripherally acting FDA (Food and Drug Administration) approved the drug for obesity [6-9]. PL is a key enzyme involved in lipid absorption especially in the step of hydrolysis of fat into glycerol and fatty acid. Therefore the pancreatic lipase inhibition results in the reduction of fat absorption and is beneficial for the regulation of metabolic disorders and obesity. PL inhibitors may also devoid of side effects generally associated with other centrally acting antiobesity agents [7].

The rising concerns over obesity as a global health hazard is relatively recent, and it has outpaced the pharmaceutical industry's ability to develop new and safe drugs. In silico screening has become a routine component of drug discovery in which the pharmacophore concept is of central importance in computer-aided drug design. It is mainly because of its successful application in medicinal chemistry and, in particular, high-throughput virtual screening [10]. Advances in computing power and improvements in pharmacophore screening algorithms have further stimulated by the increasing number of academic services and chemical vendors that offer large databases of commercially available compounds and virtual libraries
[11]. From a practical point of view, pharmacophores can be used to screen millions of high-quality compounds structures within a reasonable amount of time. Hence, nowadays, pharmacophore study has become an important method and has proven extremely successful not only in demonstrating structure-activity relationships but also in the development of new drugs [12]. In view of these facts the pharmacophore modeling, virtual screening and molecular docking studies were adopted to design novel PL inhibitors. To the best of our knowledge, this is the first ligand-based pharmacophore modeling and subsequent virtual screening study to design PL inhibitors for the purpose of developing novel anti-obesity potentials. The present study may provide deep insights into the chemical features required for pancreatic lipase inhibitory activity.

\section{MATERIALS AND METHODS}

Dataset

To develop a ligand-based pharmacophore model, a total of one hundred and thirty-three (133) molecules from diverse scaffolds with PL inhibitory activity evaluated by the same assay method (using the p-nitrophenyl butyrate (p-NPB) as substrate) were selected [13-18]. The $\mathrm{IC}_{50}$ values were converted into negative logarithm of the reported inhibitory concentrations $\left(\mathrm{pIC}_{50}\right)$. Certain compounds with no clear $\mathrm{IC}_{50}$ value (eg. indicated with>100 $\mu \mathrm{M}$ ) were omitted from the dataset. On the whole, the dataset consisted of most active, moderately active and less active molecules, and covers a range of activities ( $>5$ log units). The structural and biological activity data of PL inhibitors are tabulated in table 1 and 2 .

Generation of common pharmacophore hypothesis and 3D QSAR model

Phase (v3.2), Schrodinger was used to develop pharmacophore model and 3D QSAR validation [19]. PHASE is a highly flexible system for perception, structure alignment, activity prediction, and 3D database searching. The two-dimensional (2D) structures of the selected PL inhibitors were drawn using Chem Draw Ultra and saved 
in. mol format. Then they were imported into Maestro (v9.00, Schrödinger. Transformation of 2D structures into low energy threedimensional (3D) structures was achieved by LigPrep (v2.3), Schrodinger [20]. The conformational space was explored by the combination of Monte-Carlo Multiple Minimum (MCMM)/low Mode (LMOD) with a maximum of 1000 conformers per structure and 100 minimization steps. Each minimised conformer was filtered by limiting $10 \mathrm{~kJ} . \mathrm{mol}^{-1}$ as a relative energy window. This value sets the energy threshold relative to the lowest-energy conformer and $1.00 \AA$ as a minimum atom deviation. Conformers with a higher value than this threshold energy were discarded. All distances between pairs of corresponding heavy atoms were kept below $1.00 \AA$ for two conformers to be considered identical [21]. In the pharmacophore creating step, each ligand structure is represented by a set of points in 3D space, which coincide with various chemical features that may facilitate non-covalent binding between the compound and its target receptor. PHASE provides a built-in set of six pharmacophore features, hydrogen bond acceptor (A), hydrogen bond donor (D), hydrophobic group $(\mathrm{H})$, negatively ionisable $(\mathrm{N})$, positively ionisable (P), and an aromatic ring (R) [22].

Table 1a: Dataset used for pharmacophore modeling with actual and predicted activities of vibralactone and its derivatives (compounds 1-55).

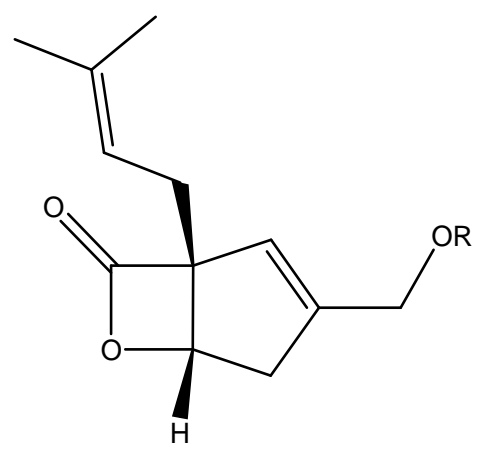

\begin{tabular}{|c|c|c|c|c|c|c|c|c|c|}
\hline $\begin{array}{l}\text { S. } \\
\text { No }\end{array}$ & $\begin{array}{l}\mathbf{R} \\
\end{array}$ & QSAR set & $\mathrm{pIC}_{50}$ & $\begin{array}{l}\text { Predict } \\
\text { ed pIC }\end{array}$ & $\begin{array}{l}\text { S. } \\
\text { No }\end{array}$ & $\mathbf{R}$ & $\begin{array}{l}\text { QSAR } \\
\text { set }\end{array}$ & $\mathrm{pIC}_{50}$ & $\begin{array}{l}\text { Predic } \\
\text { ted } \\
\text { pIC } 50\end{array}$ \\
\hline 1. & $-\mathrm{H}$ & Training & 4.326 & 4.33 & 29. & $\checkmark$ & Training & 5.611 & 5.51 \\
\hline 2. & & Training & 7.081 & 7.01 & 30. & & Training & 5.578 & 5.58 \\
\hline 3. & & Training & 7.046 & 7.07 & 31. & O & Training & 5.575 & 5.55 \\
\hline 4. & & Training & 6.939 & 6.49 & 32. & & Training & 5.424 & 5.43 \\
\hline 5. & & Training & 6.824 & 6.83 & 33. & & Test & 5.419 & 6.00 \\
\hline 6. & & Training & 6.719 & 6.44 & 34. & & Test & 5.226 & 5.92 \\
\hline 7. & & Training & 6.682 & 6.36 & 35. & & Training & 5.224 & 5.24 \\
\hline
\end{tabular}




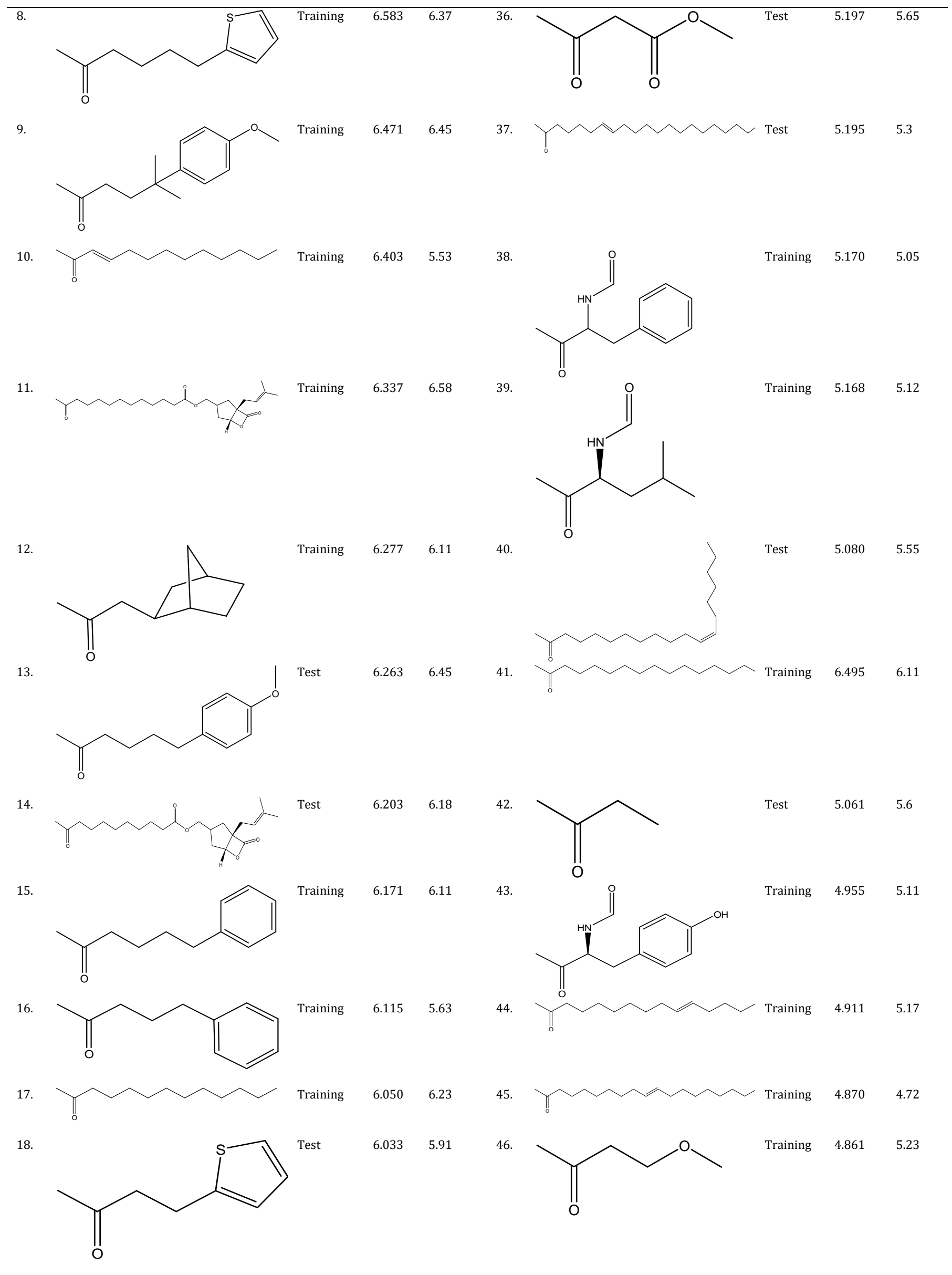


Table 1b: Dataset used for pharmacophore modeling with actual and predicted activities of vibralactone derivatives (compounds 56-92)

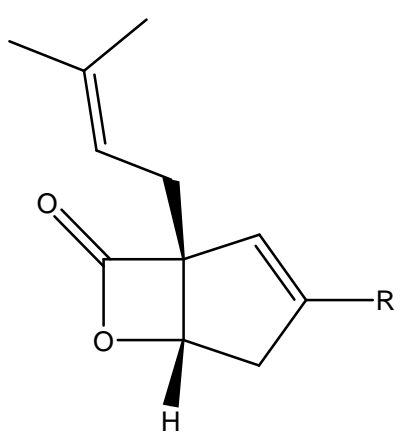

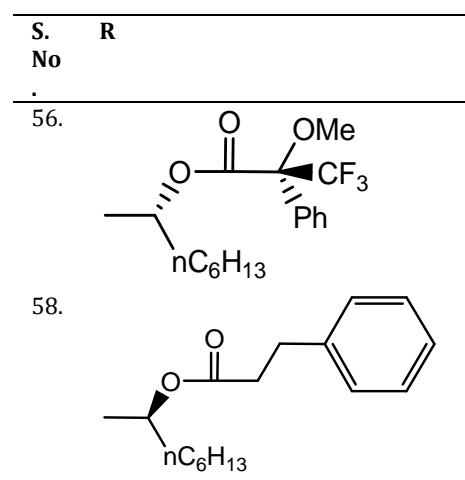

60.

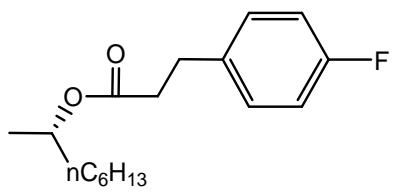

62.

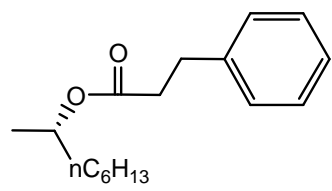

64.



66.<smiles>COc1ccc(CCCCC(=O)O[C@H](C)c2ccccc2)cc1</smiles>

68.

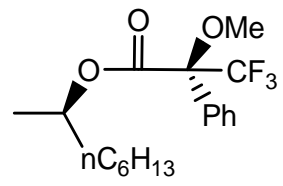

70.<smiles>CCCCCCCCC(Cc1ccccc1)=NC=O</smiles>

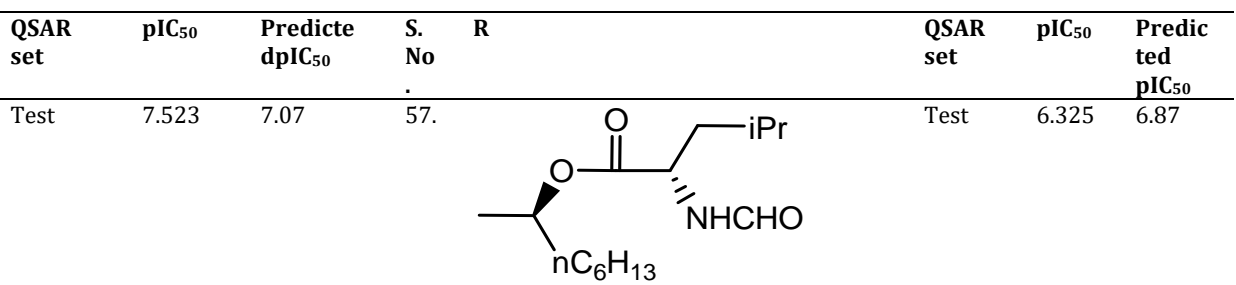

$\begin{array}{llll}\text { Test } & 7.387 & 6.63 & 59\end{array}$

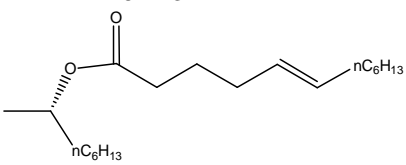

$\begin{array}{lll}\text { Traini } & 6.319 & 6.04\end{array}$ ng

Traini $\quad 6.170 \quad 6.47$<smiles>CCCC[C@H](C)OC(=O)[C@@H](N)Cc1ccccc1</smiles>

63.<smiles>CCCCCC(C)C[C@H](N)C(=O)OC(C)C</smiles>

65.

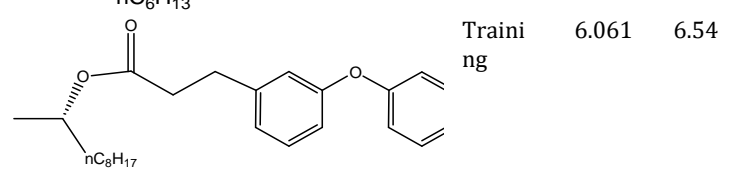

67.<smiles>C[C@H](OC(=O)[C@@H](C=O)Cc1ccccc1)c1ccccc1</smiles>

Test $\quad 6.060 \quad 6.47$

69.

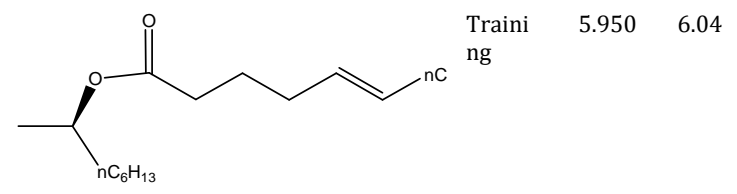

$\begin{array}{llll}\text { Training } & 7.167 & 7.21 & 71 .\end{array}$

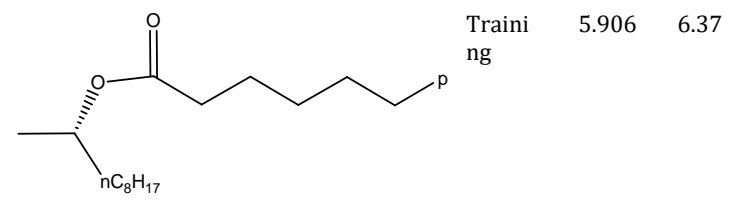




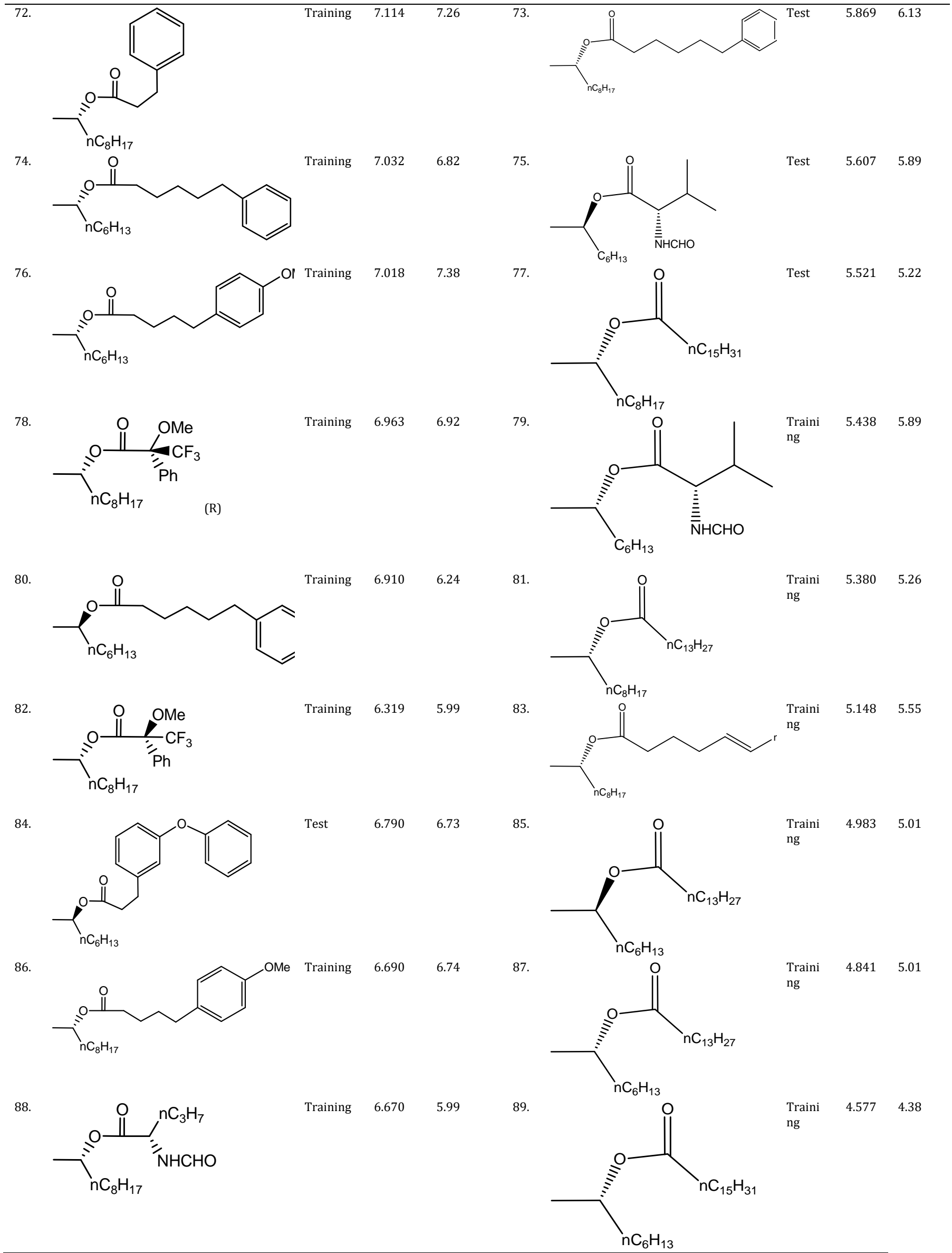




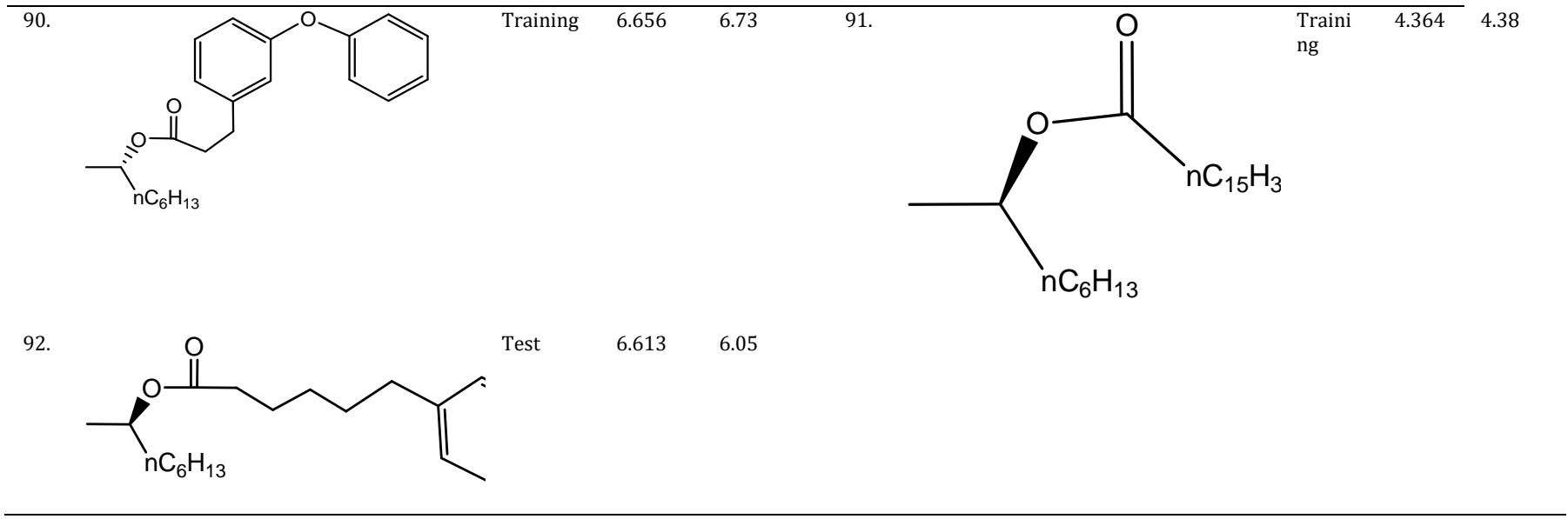

Table 1c: Dataset used for pharmacophore modeling with actual and predicted activities of vibralactone derivatives and standard drug orlistat (compounds 93-107)
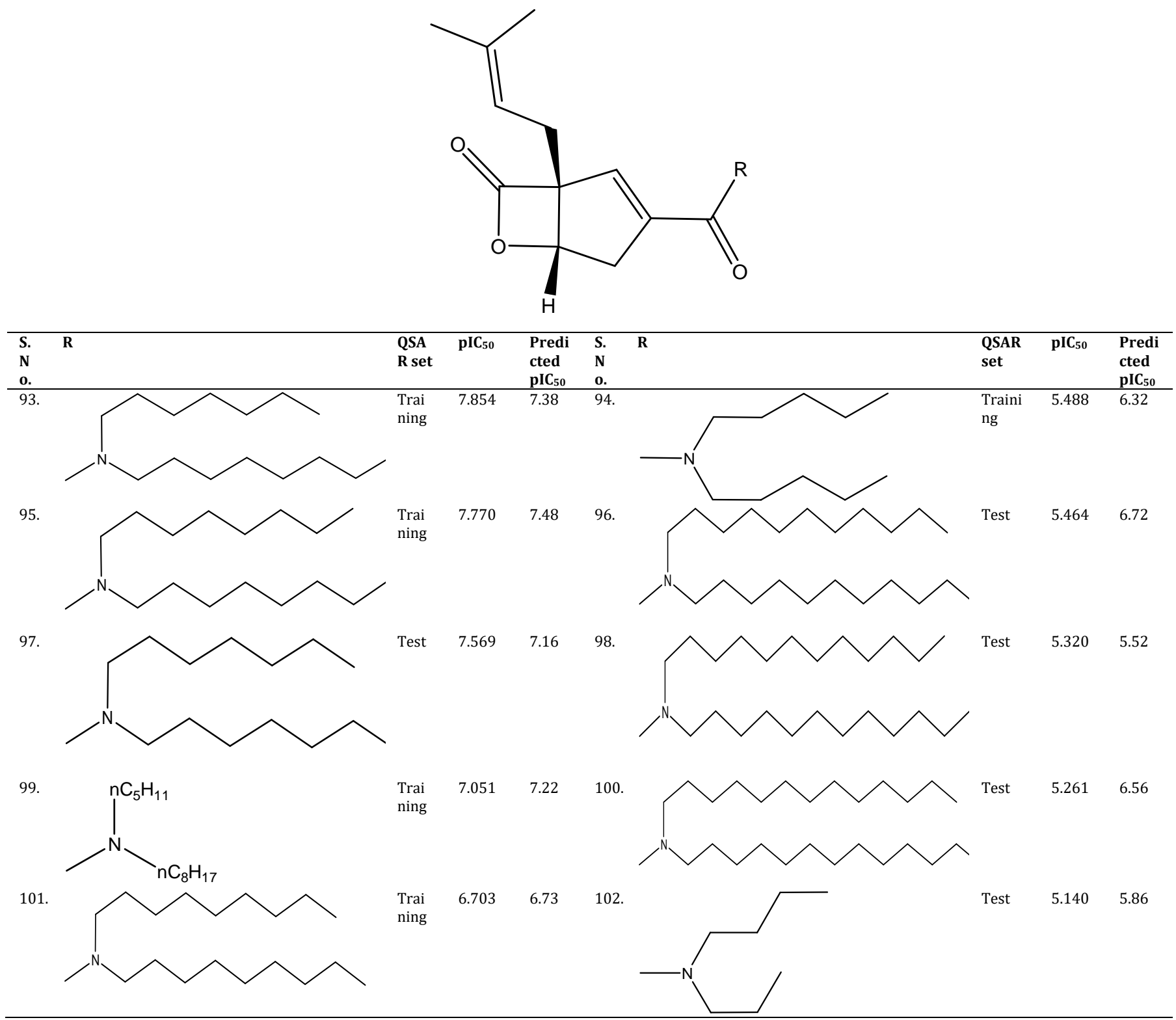


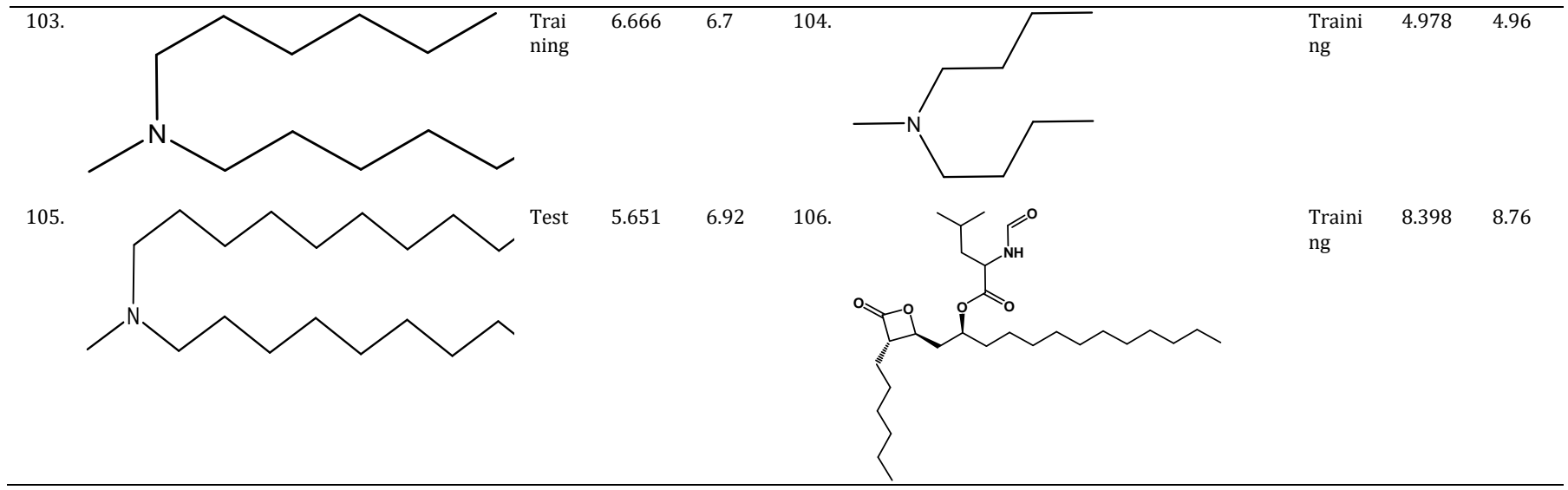

Table 2: Dataset used for pharmacophore modelling with actual and predicted activities of some natural products (compounds 107-133)




117.<smiles>Oc1ccc(CCCc2ccc(O)cc2O)cc1</smiles>

119.<smiles>COc1cc(C)ccc1CCCc1ccc(O)cc1</smiles>

Training $\quad 4.1$

3.81

1.<smiles>C=C1C=CC(O)(CCCc2ccc(O)cc2)C(OC)=C1</smiles>

123.<smiles>C=CC(=C)C1CC(=O)c2c(O)cc(O)c([C@]3(C)O[C@H](CO)[C@@H](O)[C@H](O)[C@H]3O)c2O1</smiles>

Training $\quad 4.5 \quad 4.63$

125.



127.

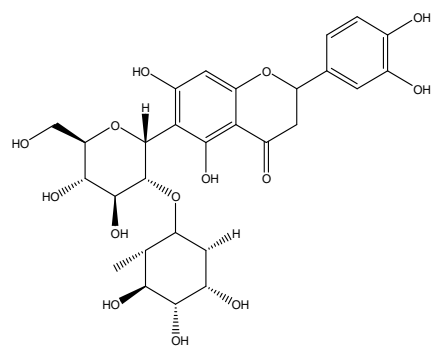

129.

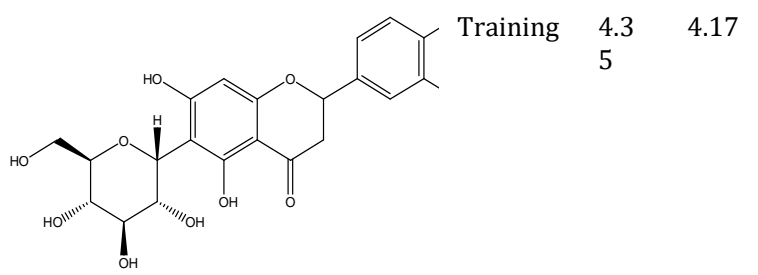

118.

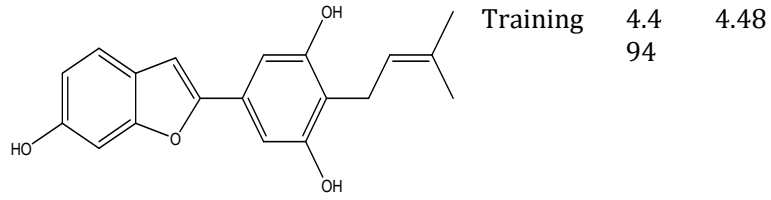

120.

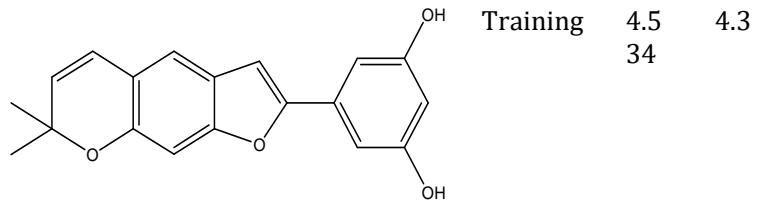

122.<smiles>CC(C)=CCc1c(O)ccc(C/C=C/c2ccc(O)cc2O)c1O</smiles>

$\begin{array}{lll}\text { Training } & 5.2 & 5.24 \\ & 07 & \end{array}$

124.<smiles>COC(=O)C[C@]1(O)C[C@@H](O)[C@H](O)[C@H](OC(=O)/C=C/c2ccc(O)c(O)c2)C1</smiles>

$\begin{array}{lll}\text { Training } & 4.4 & 4.5\end{array}$

126

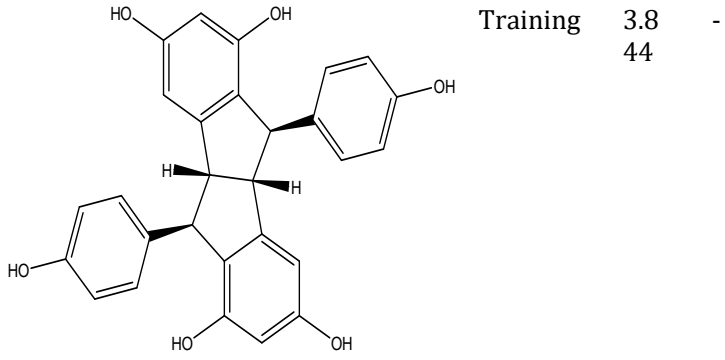

128.

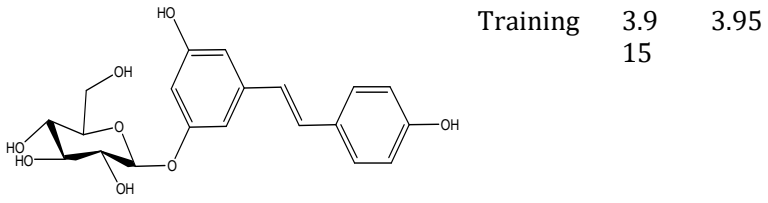
130.

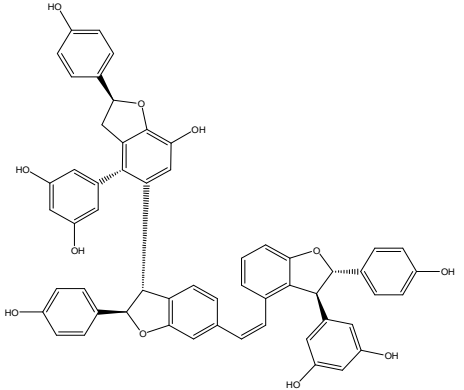


131.<smiles>CC(C)c1ccc(-c2cc(=O)c3ccc(O)cc3o2)c(O)c1</smiles>

133.<smiles>O=S(=O)(O)Oc1ccc(C2CCc3ccc(O)cc3O2)cc1</smiles>

4.34 4.2 132

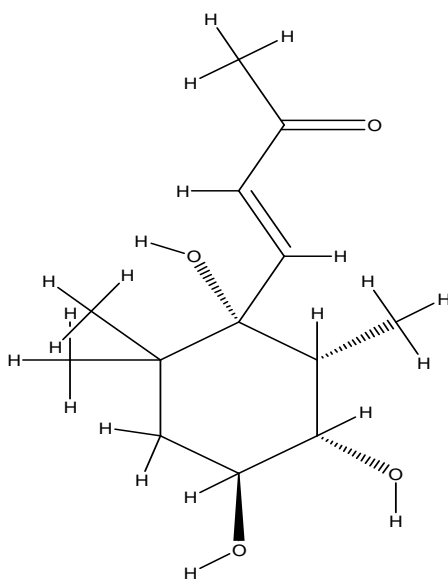

Training

5.1

73

\section{2}

For pharmacophore generation active and inactive thresholds of $\mathrm{pIC}_{50}, 7.000$ and 4.500 respectively were applied to the dataset. This yields 19 actives and 17 inactives. Hypotheses were generated by a systematic variation of the number of sites $\left(n_{\text {sites }}\right)$ and the number of matching active compounds $\left(n_{a c t}\right)$.

With $n_{\text {act }}=n_{\text {act_tot }}$ initially $\left(n_{\text {act_tot }}\right)$ is the total number of active compounds in the training set), $n_{\text {sites }}$ was varied starting from 7 to 3 until at least one hypothesis was found and scored successfully in this study. The hypotheses were scored using default parameters [23].

All hypotheses produced in the last step were then used to build 3D QSAR models. The dataset was randomly divided into a training set of 102 compounds and a test set of 31 compounds (standard 3:1 ratio) [24]. The most inactive and active molecules were kept in the training set.

\section{Model validation}

The common pharmacophore hypotheses successfully generated were scored by correlating the observed and predicted activity for the set of 102 training molecules. The Maximum number of PLS factors which can be used is N/5 (where $\mathrm{N}$ is a number of ligands in the training set). The increase in PLS factors could lead to overfitting of data. In this study, we used three PLS factors to evaluate the pharmacophore model. The model was tested for its predictive ability against a decoy test set.

The GH scoring has been applied to quantify model selectivity precision of hits and the recall of actives from a 918 molecule dataset consisting of known actives and inactives of PL target. Of these molecules, 18 compounds are known inhibitors of PL while the other 900 molecules were decoys. The decoy set was created using DUD. E (http://dude. docking. org/generate) [25].

\section{Database screening}

The best pharmacophore model was used to retrieve molecules with desired chemical features from the Phase database [Phase CAC (Commercially Available Compounds) database]. This database has $4.3 \times 10^{6}$ molecules with the unique identifier code. Conformers were generated in PHASE using the option "generate conformers during search" by setting it as a default. The search process in PHASE is normally performed in two steps: finding and fetching.

\section{Docking studies}

The retrieved compounds by virtual screening were subjected to docking by Glide (v5.6), Schrodinger. The crystal structure of porcine PL (PDB ID 1LPB) was downloaded from protein data bank [26]. The protein was prepared for docking with the Protein Preparation Wizard workflow of Maestro, Schrodinger. Glide (Grid-Based Ligand Docking with Energetics) treats the ligands with a fully flexible all-atom representation and the receptor with a rigid grid depiction [27]. The grid was generated by applying a van der Waals radii scaling factor of 1.00 with a partial charge cut-off of less than $0.25 \mathrm{e}$. The co-crystal ligand was used to centre docking box with a size capable of accommodating ligands with a length of $\leq 20 \AA$. Docking calculations were performed with Glide using Standard precision (SP) and Extra precision (XP) modes. XP Scoring was carried out on the energyminimized conformations and re-scored using Schrödinger's proprietary Glide Score (G-Score) scoring function [28, 29].

\section{RESULTS AND DISCUSSION}

The primary goal of this study is to identify essential structural features that are responsible for potent PL inhibitory activity. To achieve this, ligand-based pharmacophore modelling and atom based 3D QSAR were performed in PHASE module of Schrodinger. Subsequently, database searching in PHASE CAC database and docking studies were also done to emphasize the scope of this study.

\section{Pharmacophore modeling}

Based on the structure of actives and inactive and its occupancy of the pharmacophoric features, several four and five points CPHs were generated from the list of variants. The four featured probable CPHs were not considered for scoring analysis as they failed to match with the common sites of active molecules. A total of 4383 five featured CPHs belonging to two types AAHHH and AAAHH (table 3) were subjected to PHASE scoring procedure through three different phases such as survival, surv-inactive, posthoc (table 4).

After applying the scoring function for five featured CPHs using default values, $51 \mathrm{CPHs}$ belonging to AAAHH survived and therefore they were used for the generation of 3D QSAR models. Focusing only on those pharmacophore models whose scores ranked in the top 1\% [21], the most predictive QSAR model was found to be associated with the five point hypothesis AAAHH (Three hydrogen bond acceptor and two hydrophobic functions). 
Table 3: Identified pharmacophore hypotheses

\begin{tabular}{ll}
\hline Variant & Maximum hypothesis \\
\hline AAAHH & 4242 \\
AAHHH & 141 \\
\hline
\end{tabular}

Table 4: Best pharmacophore hypotheses according to scoring values

\begin{tabular}{|c|c|c|c|c|}
\hline Model & Survival-active & Survival-inactive & Post-hoc & \# matches \\
\hline AAAHH.5825 & 3.431 & 1.783 & 3.431 & 18 \\
\hline АААНН.8367 & 3.431 & 1.783 & 3.431 & 18 \\
\hline АААНН.7058 & 3.431 & 1.783 & 3.431 & 18 \\
\hline AAAHH.4053 & 3.431 & 1.783 & 3.431 & 18 \\
\hline АААНН.503 & 3.386 & 1.678 & 3.386 & 18 \\
\hline АААНН.2704 & 3.386 & 3.386 & 3.386 & 18 \\
\hline АААНH.1323 & 3.386 & 3.386 & 3.386 & 18 \\
\hline АААНН.1364 & 3.386 & 3.386 & 3.386 & 18 \\
\hline АААНН.5830 & 3.372 & 1.703 & 3.372 & 18 \\
\hline АAАНH.8373 & 3.372 & 1.703 & 3.372 & 18 \\
\hline АAАНH.7062 & 3.372 & 1.703 & 3.372 & 18 \\
\hline AAAHH.4058 & 3.372 & 1.703 & 3.372 & 18 \\
\hline АААНН.3927 & 3.371 & 1.692 & 3.371 & 18 \\
\hline АААНН.6893 & 3.371 & 1.692 & 3.371 & 18 \\
\hline AАAНH.5722 & 3.371 & 1.692 & 3.371 & 18 \\
\hline АААНН.4713 & 3.371 & 1.692 & 3.371 & 18 \\
\hline АААНН.8289 & 3.371 & 1.692 & 3.371 & 18 \\
\hline АААНН.2701 & 3.339 & 1.666 & 3.339 & 18 \\
\hline АААНН.8370 & 3.335 & 1.679 & 3.335 & 18 \\
\hline АААНН.7061 & 3.335 & 1.679 & 3.335 & 18 \\
\hline AAAHH.4056 & 3.335 & 1.679 & 3.335 & 18 \\
\hline АААНН.5828 & 3.335 & 1.679 & 3.335 & 18 \\
\hline АAАНH.1362 & 3.335 & 1.661 & 3.335 & 18 \\
\hline АААНН.8336 & 3.332 & 1.661 & 3.332 & 18 \\
\hline АААНН.5795 & 3.332 & 1.661 & 3.332 & 18 \\
\hline AAAHН.4821 & 3.332 & 1.661 & 3.332 & 18 \\
\hline AАAНH.7001 & 3.332 & 1.661 & 3.332 & 18 \\
\hline AАAНH.4008 & 3.332 & 1.661 & 3.332 & 18 \\
\hline АААНН.1321 & 3.325 & 1.652 & 3.326 & 18 \\
\hline АААНН.228 & 3.297 & 1.663 & 3.297 & 18 \\
\hline АААНН.2786 & 3.297 & 1.663 & 3.297 & 18 \\
\hline АAАНH.1504 & 3.297 & 1.663 & 3.297 & 18 \\
\hline АААНН.1830 & 3.297 & 1.663 & 3.297 & 18 \\
\hline АААНН.5818 & 3.291 & 1.647 & 3.291 & 18 \\
\hline АААНН.8359 & 3.291 & 1.647 & 3.291 & 18 \\
\hline АAАНH.4046 & 3.291 & 1.647 & 3.291 & 18 \\
\hline AАAHН.7050 & 3.291 & 1.647 & 3.291 & 18 \\
\hline АААНН.6891 & 3.291 & 1.647 & 3.291 & 18 \\
\hline АAАНH.8287 & 3.291 & 1.647 & 3.291 & 18 \\
\hline АААНН.5720 & 3.291 & 1.647 & 3.291 & 18 \\
\hline АААНН.3978 & 3.257 & 1.646 & 3.257 & 18 \\
\hline АААНН.7022 & 3.257 & 1.646 & 3.257 & 18 \\
\hline АААНН.6887 & 3.248 & 1.572 & 3.248 & 18 \\
\hline АААНН.3913 & 3.248 & 1.572 & 3.248 & 18 \\
\hline АAАНH.5712 & 3.248 & 1.572 & 3.248 & 18 \\
\hline АААНН.8279 & 3.248 & 1.572 & 3.248 & 18 \\
\hline АААНН. 2703 & 3.195 & 1.488 & 3.195 & 18 \\
\hline АААНН.1363 & 3.195 & 1.488 & 3.195 & 18 \\
\hline АААНН.49 & 3.195 & 1.488 & 3.195 & 18 \\
\hline AАAHН.1322 & 3.195 & 1.488 & 3.195 & 18 \\
\hline
\end{tabular}

The pharmacophoric inter sites distance and angles are shown in fig. $1 \mathrm{a}$ and $1 \mathrm{~b}$ respectively. The most active molecule was scored with the highest fitness and it was automatically selected as the reference ligand.

The most active and inactive compounds of the training set as well as the test set mapped to the pharmacophore model are depicted in fig. 2a-2d. All the pharmacophoric features highlight the importance of acceptors and hydrophobic interactions. From the pharmacophore model, it was found that for a good pancreatic lipase inhibitory activity molecules should contain three hydrogen bond acceptor groups such as carbonyl or sulphonyl at particular distance and angle.

Also, molecules that are able to form hydrophobic interactions with the target will show PL inhibitory activity. 

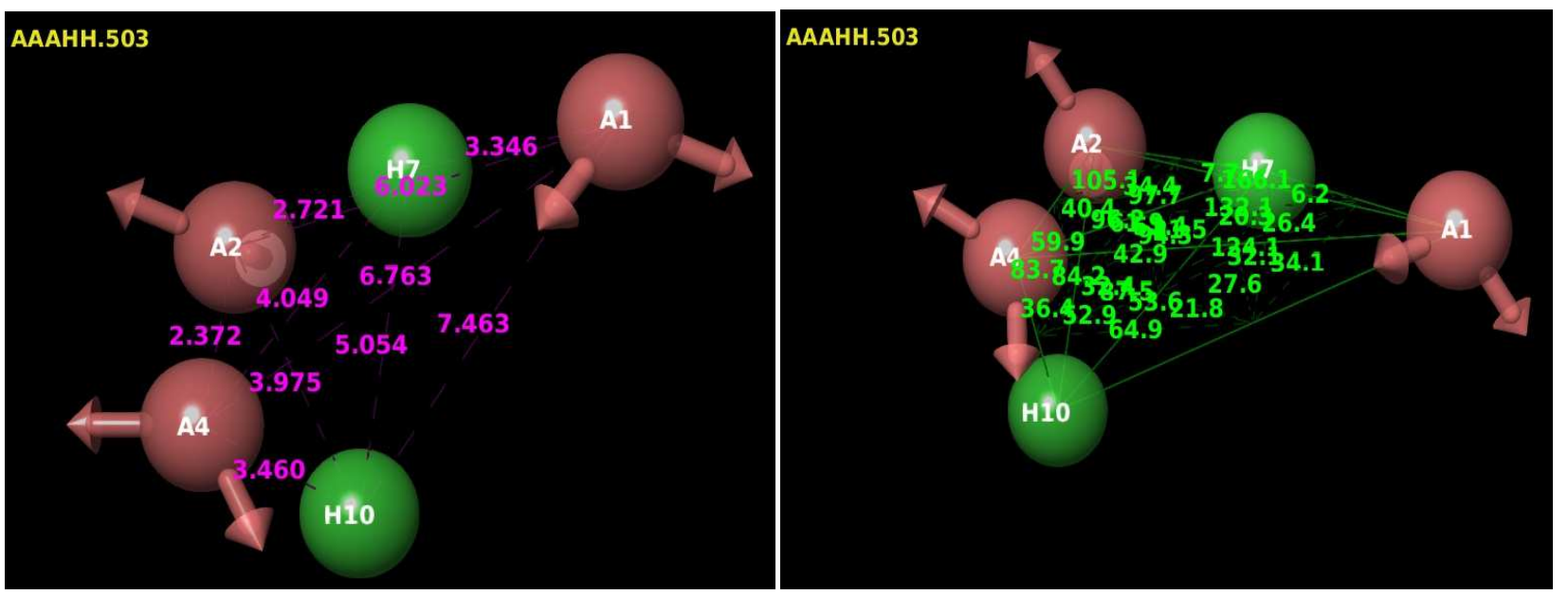

Fig. 1: The Pharmacophore hypothesis generated from the present study. (a) Intersite distances are expressed in Angstroms. (b) Intersite angles are expressed in degrees

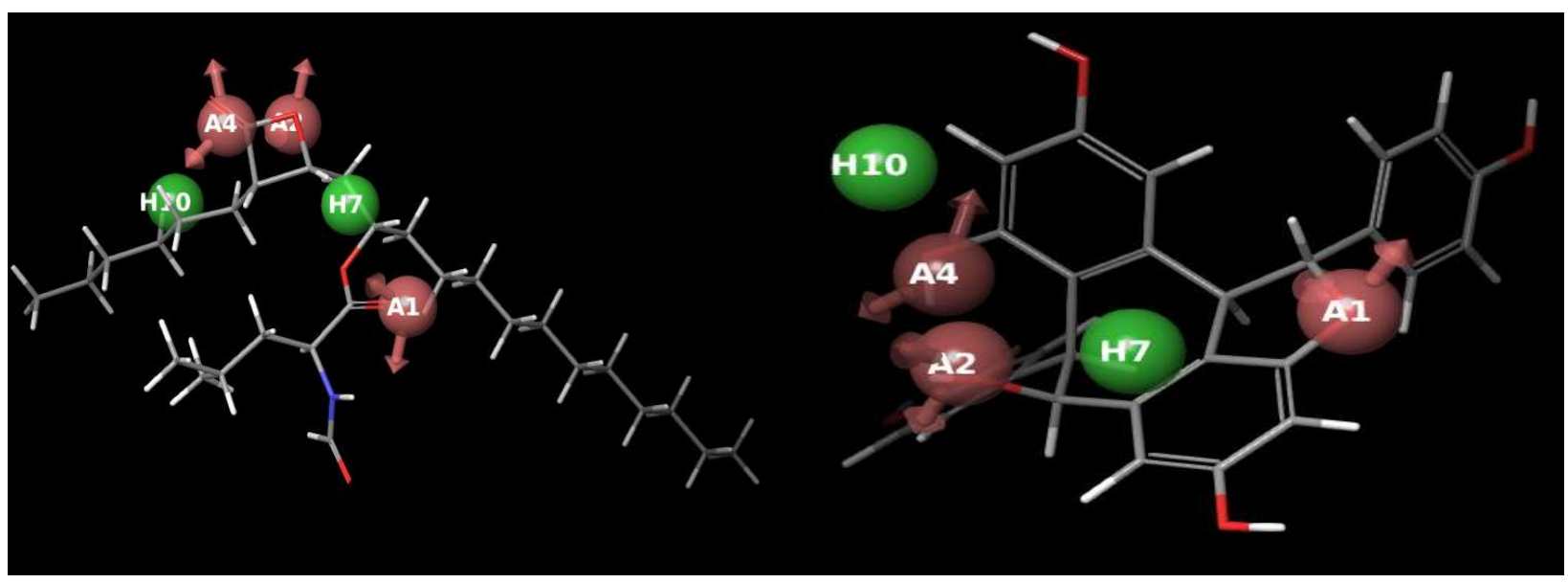

Fig. 2: Pharmacophore model (AAAHH) aligned with the most active and inactive compounds in data set. Pink sphere: A-acceptor; Green sphere: $H$ hydrophobic; (a) the most active compound (b) the least active compound in the data set

\section{Contour plot analysis}

Contour plot analysis was done to understand the influence of 3D structural features on pancreatic lipase inhibition. Blue cubes indicate positive contributions and negative contributions are indicated by red cubes. Fig. 4a illustrates the pharmacophoric site map with the most active ligand of the training set (compound no. 106, pIC $_{50}$ 8.398).

For hydrogen bond accepting attributes (the blue cubes around the beta-lactone ring and carbonyl ring of N-formyl-L-asparagine (A1, A2 and A3 pharmacophoric site)) specified the preference of hydrogen bond acceptor groups at these positions.

The two hydrophobic pharmacophoric sites (H7 and H10) map very well with the hydrophobic aliphatic chains namely tridecyl and hexyl in the third and fourth position of the beta-lactone respectively. Fig. $4 \mathrm{~b}$ represents the overlay of the most inactive ligand (compound $108, \mathrm{pIC}_{50} 3.842$ ) in training set on the generated pharmacophore hypothesis. We can see that the molecule does not map well into the sites of the developed pharmacophore.

Red cubes around the pharmacophore sites indicated the unfavourable structural features of the compound and also explain for its lower potency. The rigid and fused aromatic ring system devoid of hydrogen bond acceptor features may be the reason for the poor overlay of this compound with pharmacophoric sites. The chemical classes like stilbenoids, alkaloids, flavonoids, and flavones used in the dataset are all devoid of hydrogen bond acceptor and hydrophobic features and also exhibit poor activity against PL.

The compounds possessing either hydrogen bond acceptors or hydrophobic features exhibit moderate inhibitory activity against PL. This corroborates the significance of the hydrogen bond acceptor and the hydrophobic feature for PL inhibitory activity.

\section{D QSAR model and validation}

The statistical parameters such as $\mathrm{r}^{2}$ (squared correlation coefficient), $Q^{2}$ (cross-validated correlation coefficient), Pearson-R, SD (standard deviation), RMSE (root mean square error), and Fvalue (variance ratio)for the selected $\mathrm{CPH}$ are tabulated in table 5 . The good $r^{2}(0.9389)$ and q2 (0.4016) value shows the predictive ability of the model. The predicted $\mathrm{pIC}_{50}$ values by the constructed 3D-QSAR model are listed in table 1 and 2 and shown in fig. 3.

The high value of $\mathrm{R}^{2}$ and variance ratio (F) observed for this model indicates its statistical robustness. The value of statistical significance $\mathrm{P}<0.05$ indicates a greater degree of confidence. This means $\mathrm{F}$ is significant at $95 \%$ level. The low SD and RMSE obtained in the present study indicates that the model is significant. 

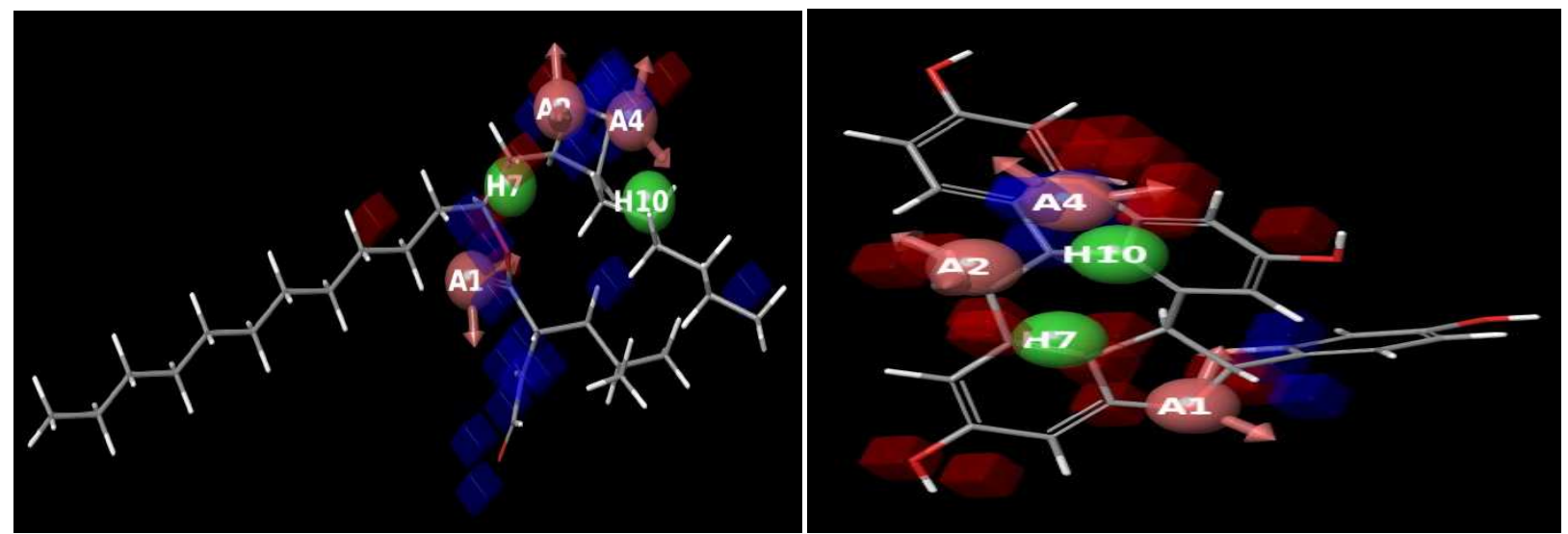

Fig. 4: Visual representation of atom-based AAAHH pharmacophore model; (a) the most active molecule (b) most inactive molecule in the dataset

Table 5: 3D QSAR statistical parameters of the selected model

\begin{tabular}{|c|c|c|c|c|c|c|c|c|c|}
\hline Hypothesis & PLS & SD & $\mathbf{R}^{2}$ & $\mathbf{F}$ & $\mathbf{P}$ & Stability & RMSE & $\mathbf{Q}^{2}$ & Pearson-r \\
\hline \multirow[t]{5}{*}{ AAAHH.503 } & 1 & 0.8105 & 0.4843 & 93 & $6.6 e-16$ & 0.924 & 0.5166 & 0.2579 & 0.5679 \\
\hline & 2 & 0.5705 & 0.747 & 144.7 & $5.629 \mathrm{e}-30$ & 0.7899 & 0.5081 & 0.2821 & 0.6128 \\
\hline & 3 & 0.4151 & 0.8675 & 211.6 & $1.994 \mathrm{e}-42$ & 0.6489 & 0.4779 & 0.3647 & 0.6918 \\
\hline & 4 & 0.3301 & 0.9171 & 265.4 & $5.69 e-51$ & 0.5674 & 0.4591 & 0.4138 & 0.6936 \\
\hline & 5 & 0.2848 & 0.9389 & 291. & $5.087 \mathrm{e}-56$ & 0.5478 & 0.4639 & 0.4016 & 0.6961 \\
\hline
\end{tabular}



Fig. 3: Plot of observes vs predicted $\mathrm{pIC}_{50}$ for training and test set

\section{Database screening and docking studies}

At the end of searching in Phase database [Phase CAC (Commercially Available Compounds)], 983 hits that matched with the pharma- cophore hypothesis were obtained. These compounds were subjected to an initial filtration by the Lipinski rule of five [30] and predicted $\mathrm{pIC}_{50}$ values $>7.00$, which in turn yielded 178 compounds. The selection of hit molecules from 178 compounds was purely based on obtaining a better G-Score and required interactions with active site amino acids in the target crystal structure of pancreatic lipase.

The 178 compounds obtained from the initial filtration were subjected to SP docking analysis on $1 \mathrm{LPB}$ with hydrogen bonding constraints with at least one of the residues of the catalytic triad. Of the 93 compounds that satisfied these hydrogen bonding constraints, only those compounds with GlideScore >-8.00 (absolute value) were selected for further refining with the second run of docking in XP mode.

The second docking XP run identified 5 potentially high active hits with a GlideScore>-8.00 (absolute value). These five hits were then superimposed on the pharmacophore hypothesis generated from our studies. Fig. 5 shows the superimposed hit molecule map well with the pharmacophore points AAAHH.

All the five hit molecules-1LPB complexes showed important hydrogen bonding interactions with key amino acid residues. The mode of interaction and the amino acids involved are listed in table 6.

Table 6: Glide score and interactions of the hit molecules with 1LPB

\begin{tabular}{|c|c|c|c|}
\hline \multirow{2}{*}{ Molecule code } & \multicolumn{2}{|l|}{ Interaction with 1 LPB } & \multirow[t]{2}{*}{ Glide score } \\
\hline & Amino acid residue involved & Type of interaction & \\
\hline \multirow[t]{3}{*}{ CACPD2011a-0000904029 } & HIP 263 & 1 Hydrogen bond and 1 pi-pi stacking & -9.15 \\
\hline & SER 152 & 1 hydrogen bond & \\
\hline & PHe 215 & 1 pi-pi stacking & \\
\hline \multirow[t]{4}{*}{ CACPD2011a-0002012951 } & PHE 215 & 1 pi-pi stacking & -8.84 \\
\hline & HIP 263 & 2 hydrogen bonds & \\
\hline & PHE 77 & pi-pi stacking & \\
\hline & TYR 114 & pi-pi stacking & \\
\hline \multirow[t]{3}{*}{ CACPD2011a-0002012956 } & Thr 255 & 1 hydrogen bond(back bone) & -8.87 \\
\hline & HIP 263 & 1 hydrogen bond & \\
\hline & TYR 114 & 1 pi-pi stacking & \\
\hline \multirow[t]{3}{*}{ CACPD2011a-0002070418 } & PHE 77 & 1 hydrogen bond & -8.64 \\
\hline & ARG 256 & pi-cationic interaction & \\
\hline & TRP 252 & 1 pi-pi stacking & \\
\hline \multirow{3}{*}{ CACPD2011a-0002212015 } & TYR 114 & 1 pi-pi stacking & -8.72 \\
\hline & PHE 77 & 2 hydrogen bond & \\
\hline & HIP 263 & 1 hydrogen bond & \\
\hline
\end{tabular}




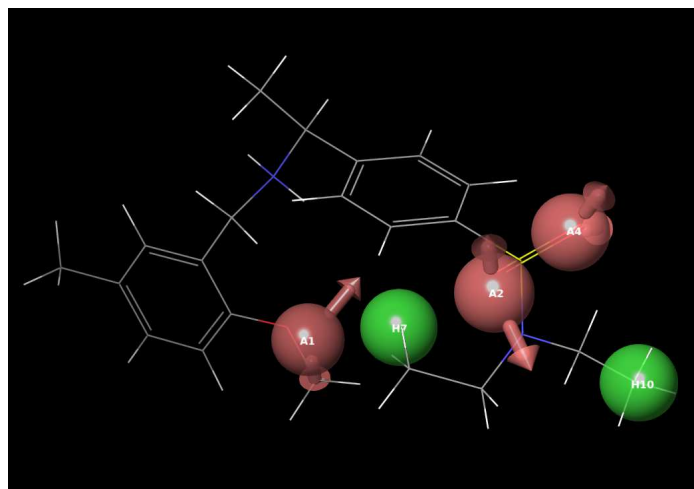

Fig. 5: Superimposition of top-scored hit molecule CACPD2011a0000904029 with the pharmacophore hypothesis AAAHH

Earlier, crystallographic studies revealed that PL [26] consisted of two structural domains: an amino-terminal domain spanning residues 1-336 which contain the active site and a carboxy-terminal domain spanning residues 337-449 in which the colipase binding site is present. In human PL the foremost catalytic serine residue essential for lipid hydrolysis is present at the N-terminal domain and is part of Ser-Asp-His triad of the active site. This catalytic triad of PL is chemically analogous and structurally distinct to that of serine proteases. The essential structural features that are required for ester hydrolysis during lipid digestion were discussed by various Xray crystallographic studies of PL and PL-colipase complex. PL possesses i) catalytic N-terminal domain (residues1-336) which contains catalytic triad ii) Non-catalytic C-terminal domain (residues 337-449) in which binding site for colipase is present and iii) a lid domain also called as surface loop (residues 237-261) that cover the active site in closed conformation and exposes the active site for the substrate in open conformation, especially when the enzyme binds with colipase [31-33]. The three important regions of open conformation of pancreatic lipase that allows the substrate to access the active site are a catalytic triad, oxyanion hole which stabilizes the transition state intermediate formed during catalysis, and a remarkable continuous hydrophobic plateau. [26, 34]. The amino acid residues of the above-mentioned regions are.

i) Catalytic triad residues-Ser 152, Asp 176, His 263

ii) Hydrophobic zone-Ala178, Phe215, Prol80, Tyrll4, Leu213

iii) Oxyanion hole-Phe 77, Leu 153

Five molecules were selected from the primary hits by considering glide score and key interactions with PL enzyme. All the five molecules showed good interactions especially with the above mentioned catalytic triad, oxyanion hole and hydrophobic zone of the target enzyme.
CACPD2011a-0000904029 comprises a sulphonamide moiety and two phenyl rings isolated by $\mathrm{N}$, the $\mathrm{N}$-dimethyl amino group. With the glide score-9.15, this compound establishes two hydrogen bondings with the active site residues Ser 152 and Hip 263. With amino acid residues Phe 215 and Hip 263 it established two $\pi-\pi$ stackings. All these interactions are attributed to good binding affinity. When the binding mode is compared with the standard drug orlistat, the compound CACPD2011a-0000904029 also shows a hydrogen bonding with ser 152 [35]. So it may exert considerable anti-obesity activity.

Tertiary nitrogen of pyrazole ring of CACPD2011a-0002012951 (fig. $6 \mathrm{~b})$ showed divalent side chain hydrogen bond with HIP 263. The terminal phenyl rings established three $\pi-\pi$ stackings that are associated with Phe 77, Phe 215 and Tyr 114, the residues of a hydrophobic patch formed during open conformation. The binding mode of the CACPD2011a-0002012956 complex is given in the fig. 6c. It illustrates the two hydrogen bondings exhibited by the oxygen atom of acetyl group attached to indoline nitrogen with Hip 263 and the nitrogen atom of amide group linked with phenyl ring with Thr 255. As shown in MUP (Methoxyundecyl phosphinic acid)-PL complex [26] the compounds CACPD2011a-0002012951 and CACPD2011a-0002012956 show important interactions with oxyanion hole and hydrophobic zone. These interactions are essential for fat hydrolysis. So it was observed that these molecules can readily replace the fat molecule and prevent the fat hydrolysis.

The complex 1LPB-CACPD2011a-0002070418 with glide energy of8.64 is formed by different interactions that are shown in fig. $6 \mathrm{~d}$. These electrostatic forces include hydrogen bond, $\pi$-cationic interaction, and $\pi-\pi$ interaction. The hydrogen bonding is established by the amino group of semicarbazide type of moiety with Phe 77 of oxyanion hole. Pyrazole ring of indoline establishes the $\pi$-cationic interaction with Arg 256, one of the key residues of lid domain and hydrophilic pocket. Phenyl ring of indoline interacts with Trp 252 via $\pi-\pi$ stacking. Egloff et al. [26] stated that Trp 252 is part of the lid domain and fills the active site especially when the enzyme is in a closed conformation. Its removal starts an array of conformational changes, lid opening, and exposes the active site to the substrate. So these interactions clearly describe the ability of the compound 1LPB-CACPD2011a-0002070418 to stop the array of conformational changes that are required for successful fat hydrolysis step. In the complex 1LPB-CACPD2011a-0002212015, three hydrogen bonds and one pi-pi interaction were observed with a glide score of-8.72. Out of the three hydrogen bonds, a divalent hydrogen bond with phe 77 was brought by the nitrogen atom of sulphonamide group. Two hydrogen bondings were established by the phenacyl ester group with amino acid residues phe 77 and Hip 263 . Another $\pi-\pi$ stacking was observed between the phenyl ring of the molecule and Tyr 114 [36, 37]. The molecule CACPD2011a0002212015 shows binding interactions with all the three essential amino acid segments such as a catalytic triad, oxy anionic whole and hydrophobic zone.

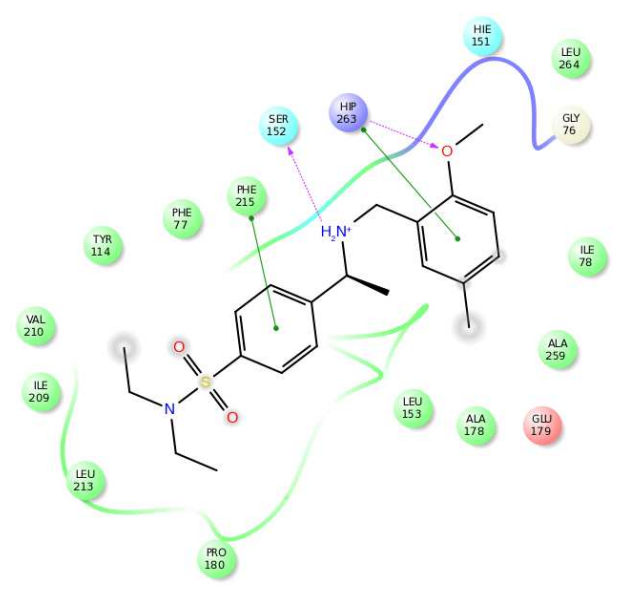

CACPD2011a-0000904029

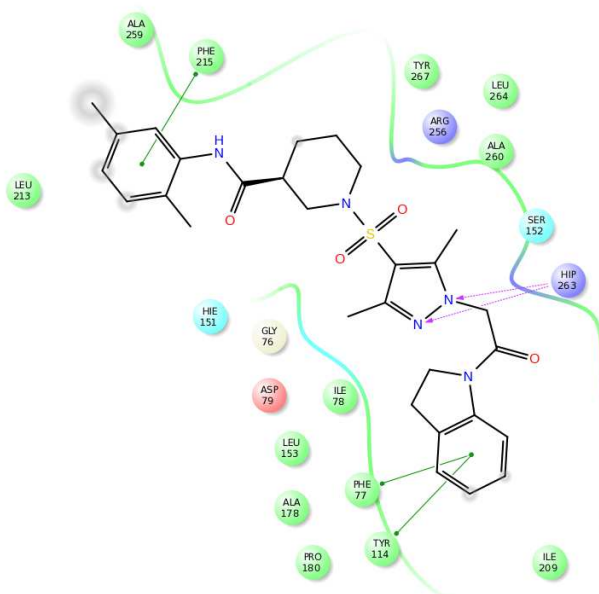

CACPD2011a-0002012951 


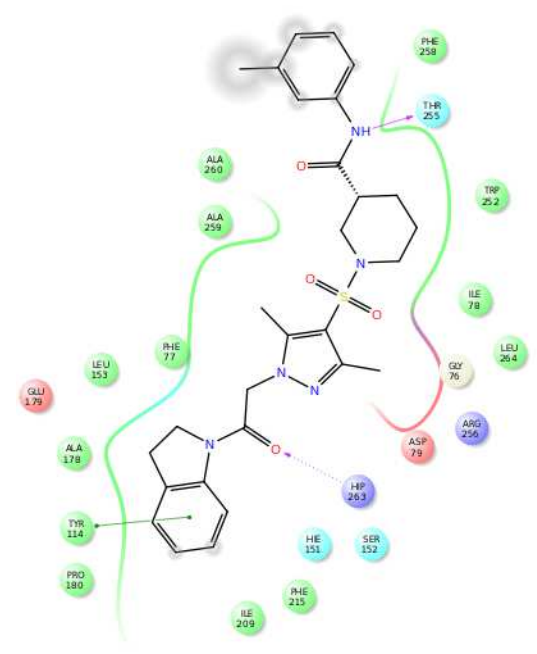

CACPD2011a-0002012956

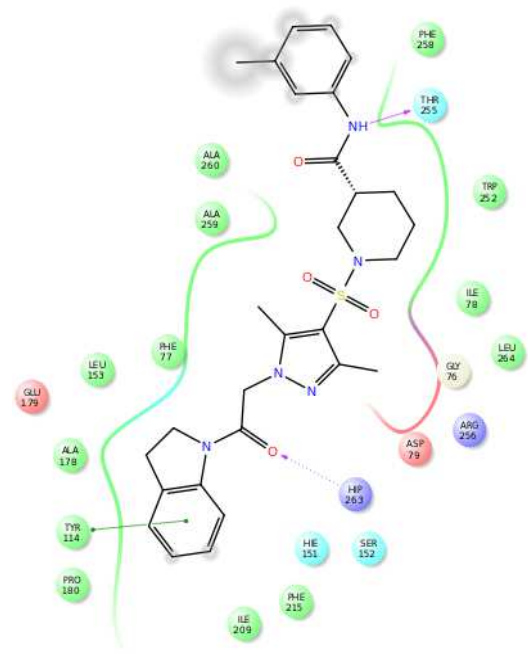

CACPD2011a-0002070418

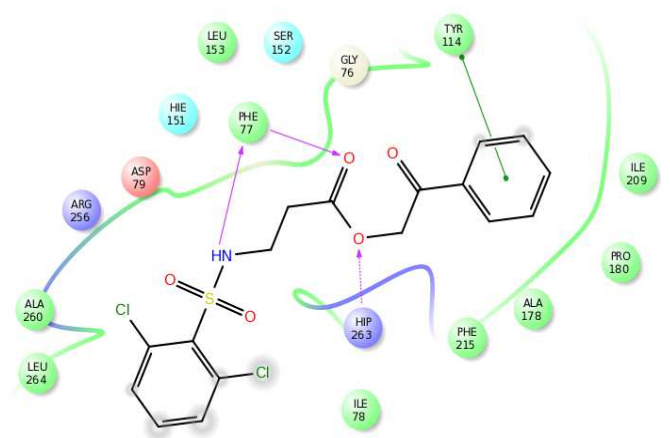

ALA

Fig. 6a-e: 2D ligand interaction diagram of hit molecules and their binding mode

Docking studies of (-)-Epigallocatechin 3-0-gallate (EGCG), which is one of major polyphenols in green tea known for its pancreatic lipase inhibitory activity with an $\mathrm{IC}_{50}$ of $0.349 \mu \mathrm{M}$ revealed that an important hydrogen bond was formed between Hydroxyl group of the compound and a residue of the catalytic triad His 263 [38]. A molecular level docking simulations of berberine (IC 50 value of 106.0 $\mu \mathrm{M}$ ) and dihydro berberine ( $\mathrm{IC}_{50}$ value of $8 \mu \mathrm{M}$ ) revealed that potential hydrophobic interactions with the key amino acids Phe215, Phe-77 and Tyr-114 are responsible for the biological activity. Also this study focused that multiple strong hydrogen bonds with Ser-152 and His-263 stabilizes the ligand-protein complex and contributes to the good binding affinity of the two alkaloids [39]. When the interactions are compared with the reported studies, it was observed that the acceptor group of the hit molecules showed hydrogen bonding with His 263. Also hydrophobic interactions with the amino acids Phe-215, Phe-77 and Tyr-114 were also observed through docking studies.

When the interactions are thoroughly analyzed, it is supposed that the hit molecules possess essential structural features for PL inhibitory activity. All the molecules had minimum one interaction with i) the residues of active site ii) ion stabilizing residues of oxy anionic hole iii) hydrophobic patch and iv) hydrophilic region. It indicates that the hit molecules interrupt the conformational changes required for the catalysis as well as compete with the substrate. In addition, all the molecules have hydrophobic enclosure reward points as given in table 7 and fig 7 . It enumerates how the molecules run parallel to the amino acid residues of the hydrophobic plateau that develops during the most active open conformation.

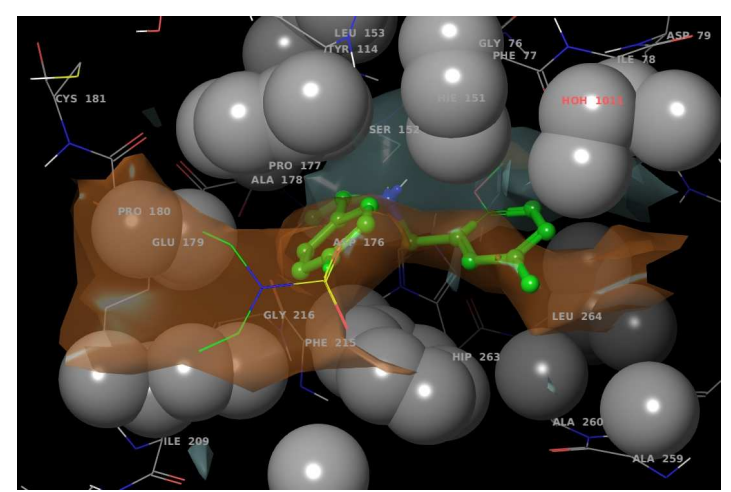

Fig. 7: Top scored hit molecule interacting with hydrophobic environment and enclosed in a hydrophobic cavity 
Table 7: Glide energy and hydrophobic enclosure reward points of the hit molecules

\begin{tabular}{lll}
\hline Molecule code & Glide energy & XP PhobEn \\
\hline CACPD2011a-0000904029 & -39.122 & -1.85 \\
CACPD2011a-0002012951 & -55.683 & -1.05 \\
CACPD2011a-0002012956 & -44.491 & -0.875 \\
CACPD2011a-0002070418 & -58.963 & -1.525 \\
CACPD2011a-0002212015 & -46.204 & -1.675 \\
\hline
\end{tabular}

\section{CONCLUSION}

In the present study, a five point 3D QSAR pharmacophore model was developed using a data set having 133 compounds. The developed pharmacophore consists of three hydrogen bond acceptor and two hydrophobic features. The model was validated and it was found to have high predictive power. The ligand-based pharmacophore model furnished structural features that are required for pancreatic lipase inhibitory activity in terms of most active and inactive ligand in the training set as well as in the test set. A database searching and docking studies were applied to identify hit molecules that match with the pharmacophore sites as well as have the ability to bind with the PL enzyme.

All the five hit molecules showed interaction with one of the amino acid residues presents either in the catalytic triad or ion stabilizing residues of oxyanion hole; the regions that actively participate in the PL-mediated lipolysis. In addition to this, hit molecules showed hydrophobic interactions with amino acid residues of the hydrophobic groove that makes the active site remain exposed during the catalysis. Taken as a whole, the hit molecules could serve as potent lead molecules and provide an opportunity for pharmacodynamics and pharmacokinetic studies to develop potent pancreatic lipase inhibitors and thereby progress in anti-obesity therapeutics. The lipid hydrolysis inhibition may be exerted through more than one binding mode and is yet to be illuminated through experimental studies.

\section{ABBREVIATIONS LIST}

PL-Pancreatic lipase, QSAR-Quantitative Structural Activity Relationship, SP-Standard precision, XP-Extra Precision, PLS-Partial Least Square, PhobEn-Hydrophobic Enclosure rewards.

\section{ACKNOWLEDGEMENT}

The authors would like to thank Dr. M. Ramanathan, Principal, PSG College of Pharmacy for providing the facilities to carry out this work and also for his valuable suggestions.

\section{CONFLICT OF INTERESTS}

\section{Declared none}

\section{REFERENCES}

1. Christensen $\mathrm{R}$, Kristensen $\mathrm{PK}$, Bartels EM, Bliddal $\mathrm{H}$, Astrup A. Efficacy and safety of the weight-loss drug rimonabant: a meta-analysis of randomised trials. Lancet 2007;370:1706-13.

2. Cheung BM. Drug treatment for obesity in the post-sibutramine era. Drug Saf 2011;34:641-50.

3. Remesh A. Obesity: pathophysiology and management-A pharmacological perspective. Asian J Pharm Clin Res 2013;6:11-3.

4. Cheung BM, Cheung T, Samaranayake NR. Safety of antiobesity drugs. Ther Adv Drug Saf 2013;4:171-81.

5. Heal DJ, Gosden J, Smith SL. A review of late-stage CNS drug candidates for the treatment of obesity. Int $\mathrm{J}$ Obes 2013;371:107-17

6. Borgström B. Mode of action of tetrahydrolipstatin. a derivative of the naturally occurring lipase inhibitor lipstatin. Biochim Biophys Acta 1988;962:308-16.

7. Shi Y, Burn P. Lipid metabolic enzymes: emerging drug targets for the treatment of obesity. Nat Rev Drug Discovery 2004;3:695-10.
8. Harrison SA, Fincke C, Helinski D, Torgerson S, Hayashi P. A pilot study of orlistat treatment in obese, non-alcoholic steatohepatitis patients. Aliment Pharmacol Ther 2004;20:623-8.

9. Torgerson JS, Hauptman J, Boldrin MN, Sjöström L. XENical in the prevention of diabetes in obese subjects (XENDOS) study: a randomized study of orlistat as an adjunct to lifestyle changes for the prevention of type 2 diabetes in obese patients. Diabetes Care 2004;27:155-61.

10. Caporuscio F, Tafi A. Pharmacophore modelling: a forty-yearold approach and its modern synergies. Curr Med Chem 2011;18:2543-53.

11. Del Rio A, Barbosa AJ, Caporuscio F, Mangiatordi GF. CoCoCo: a free suite of multi-conformational chemical databases for highthroughput virtual screening purposes. Mol Biosyst 2010;6:2122-8.

12. Chen Z, Li HL, Zhang QJ, Bao XG, Yu KQ, Luo XM, et al. Pharmacophore-based virtual screening versus docking-based virtual screening: a benchmark comparison against eight targets. Acta Pharmacol Sin 2009;30:1694-708.

13. Kim JH, Kim HJ, Kim C, Jung H, Kim YO, Ju JY, et al. Development of lipase inhibitors from various derivatives of monascus pigment produced by Monascus fermentation. Food Chem 2007;101:357-64.

14. Wei K, Wang GQ, Bai X, Niu YF, Chen HP, Wen CN, et al. Structure-based optimization and biological evaluation of pancreatic lipase inhibitors as novel potential antiobesity agents. Nat Prod Bioprospect 2015;5:129-57.

15. Liang LF, Wang T, Cai YS, He WF, Sun P, Li YF, et al. Brominated polyunsaturated lipids from the Chinese sponge Xestospongia testudinaria as a new class of pancreatic lipase inhibitors. Eur J Med Chem 2014;22:290-7.

16. Ahn JH, Liu Q, Lee C, Ahn M, Yoo HS, Hwang BY, et al. A new pancreatic lipase inhibitor from Broussonetia kanzinoki. Bioorg Med Chem Lett 2012;22(8, Suppl 1):2760-3.

17. Jeong JY, Jo YH, Kim SB, Liu Q, Lee JW, Mo EJ, et al. Pancreatic lipase inhibitory constituents from Morus alba leaves and optimization for extraction conditions. Bioorg Med Chem Lett 2015;25(11, Suppl 1):2269-74.

18. Kim YM, Lee EW, Eom SH, Kim TH. Pancreatic lipase inhibitory stilbenoids from the roots of Vitis vinifera. Int J Food Sci Nutr 2014;65:97-100.

19. Dixon SL, Smondyrev AM, Rao SN. PHASE: a novel approach to pharmacophore modeling and 3D database searching. Chem Biol Drug Des 2006;67:370-2.

20. Shivakumar D, Williams J, Wu Y, Damm W, Shelly J, Sherman W. Prediction of absolute solvation free energies using molecular dynamics Free energy pertubation and the OPLS force field. J Chem Theory Comput 2010;6:1509-19.

21. Shah UA, Deokar HS, Kadam SS, Kulkarni VM. Pharmacophore generation and atom-based 3D-QSAR of novel 2-(4methylsulfonylphenyl) pyrimidines as COX-2 inhibitors. Mol Divers 2010;14:559-68.

22. Wolber G, Seidel T, Bendix F, Langer T. Molecule-pharmacophore superpositioning and pattern matching in computational drug design. Drug Discovery Today 2008;13:23-9.

23. Zhang J, Liu G, Tang Y. Chemical function-based pharmacophore generation of selective kappa-opioid receptor agonists by catalyst and phase. J Mol Model 2009;15:1027-41.

24. Umamatheswari S, Balaji B, Ramanathan M, Kabilan S. Synthesis, antimicrobial evaluation and QSAR studies of novel piperidin-4-yl-5-spiro-thiadiazoline derivatives. Bioorg Med Chem Lett 2010;20:6909-14.

25. Mysinger MM, Carchia M, Irwin JJ, Shoichet BK. Directory of useful decoys, enhanced (DUD-E): better ligands and decoys for better benchmarking. J Med Chem 2012;55:6582-94. 
26. Egloff MP, Marguet F, Buono G, Verger R, Cambillau C, van Tilbeurgh $\mathrm{H}$. The $2.46 \mathrm{~A}^{\circ}$ resolution structure of the pancreatic lipase-colipase complex inhibited by a C11 alkyl phosphonate. Biochem 1995;34:2751-62.

27. Halgren TA, Murphy RB, Friesner RA, Beard HS, Frye L, Pollard WT, Banks JL. Glide: a new approach for rapid, accurate docking and scoring. 2. Enrichment factors in database screening. J Med Chem 2004;47:1750-9.

28. Friesner RA, Banks JL, Murphy RB, Halgren TA, Klicic JJ, Mainz DT, et al. Glide: a new approach for rapid, accurate docking and scoring. 1. Method and assessment of docking accuracy. J Med Chem 2004;47:1739-49.

29. Friesner RA, Murphy RB, Repasky MP, Frye LL, Greenwood JR, Halgren TA, et al. Extra precision glide: docking and scoring incorporating a model of hydrophobic enclosure for proteinligand complexes. J Med Chem 2006;49:6177-96.

30. Lipinski CA. Drug-like properties and the causes of poor solubility and poor permeability. J Pharmacol Toxicol Methods 2000;44:235-49.

31. Yang Y, Lowe ME. The open lid mediates pancreatic lipase function. J Lipid Res 2000;41:48-57.

32. Thomas A, Allouche M, Basyn F, Brasseur R, Kerfelec B. Role of the lid hydrophobicity pattern in pancreatic lipase activity. J Biol Chem 2005;280:40074-83.

33. Miled N, Canaan S, Dupuis L, Roussel A, Rivière M, Carrière F, et al. Digestive lipases: from three-dimensional structure to physiology. Biochimie 2000;82:973-86.
34. Winkler FK, D'Arcy A, Hunziker W. Structure of human pancreatic lipase. Nature 1990;343:771-4

35. Lüthi-Peng Q, Marki HP, Hadváry P. Identification of the activesite serine in human pancreatic lipase by chemical modification with tetrahydrolipstatin. FEBS Lett 1992;299:111-5.

36. Van Tilbeurgh H, Sarda L, Verger R, Cambillau C. Structure of the pancreatic lipase-procolipase complex. Nature 1992;359:159-62

37. Bezzine S, Carriere F, De Caro J, Verger R, De Caro A. Human pancreatic lipase: an exposed hydrophobic loop from the Cterminal domain may contribute to interfacial binding. Biochem 1998;37:11846-55.

38. Bouchagra S, Benamia F, Djeghaba Z. Docking studies of (-) Epigallocatechin-3-gallate a potential non-competitive pancreatic Lipase inhibitor. Res J Pharm Biol Chem Sci 2016;7:2493-505.

39. Mohammad M, Al-Masri IM, Issa A, Khdair A, Bustanji Y. Inhibition of pancreatic lipase by berberine and dihydroberberine: an investigation by docking simulation and experimental validation. Med Chem Res 2012;22:2273-8.

\section{How to cite this article}

- $\quad$ Maida Engels, SE Balaji B, Divakar S, Geetha G. Ligand-based pharmacophore modeling, virtual screening and molecular docking studies to design novel pancreatic lipase inhibitors. Int J Pharm Pharm Sci 2017;9(4):48-64. 